TINJAUAN PUSTAKA

\title{
Anestesi Regional pada Pasien dengan Penyakit Jantung/ Hemodinamik Tidak Stabil
}

\section{Regional Anesthesia for Patient with Heart Disease/ Unstable Hemodynamics}

\author{
Widya Istanto Nurcahyo ${ }^{\bowtie}$ \\ Bagian Anestesiologi dan Terapi Intensif, Fakultas Kedokteran, Universitas Diponegoro, \\ Semarang, Indonesia \\ ${ }^{\square}$ Koresponsdensi: widya_istanto2@yahoo.com
}

\begin{abstract}
Administering anesthesia to patients with preexisting cardiac disease is an interesting challenge. The most common cause of perioperative morbidity and mortality in cardiac patients is ischemic heart disease (IHD). Goldman et al reported that 500,000 to 900,000 (Myocard Infarcts) MIs occur annually worldwide with subsequent mortality of 10-25\%. The decision to use regional anesthesia depends on many factors. Patient characteristics, the type of surgery planned, and the potential risk of anesthesia will all have an impact on anesthesia choice and perioperative management. Losses from regional anesthesia including hypotension from the uncontrolled sympathetic blockade and the need for volume loading can cause ischemia. Management must be taken when giving local anesthesia because larger doses can cause toxicity and myocardial depression. In patients with cardiovascular disease, regional anesthesia techniques (either alone or together with general anesthesia) have the potential to provide perioperative benefits in reducing stress responsse, cardiac sympathectomy, earlier extubation, shorter hospital stay, and good postoperative analgesia. The implementation must consider not only the type of surgery performed but also the problems that exist in each patient. General anesthesia also plays an important role because it has cardioprotective properties and can increase oxygen supply. The decision to use regional anesthesia must be done carefully and carried out with proper monitoring.
\end{abstract}

Keywords: anesthesia; regional; general; cardiac; hemodynamics

\begin{abstract}
ABSTRAK
Pembiusan pasien dengan penyakit jantung sebelumnya merupakan tantangan yang menarik. Penyebab paling umum morbiditas dan mortalitas perioperatif pada pasien jantung adalah penyakit jantung iskemik (PJI). Goldman dkk. melaporkan bahwa 500.000 hingga 900.000 infark miokard terjadi setiap tahun di seluruh dunia dengan mortalitas $10-25 \%$. Keputusan untuk menggunakan anestesi regional tergantung pada
\end{abstract}


banyak faktor. Karakteristik pasien, jenis operasi yang direncanakan, dan potensi risiko anestesi semuanya akan berdampak pada pilihan anestesi dan manajemen perioperatif.

Kerugian dari anestesi regional termasuk hipotensi dari blokade simpatis yang tidak terkendali dan kebutuhan untuk loading volume dapat menyebabkan iskemia. Pemberian anetesi lokal dalam dosis besar juga harus mempertimbangkan risiko toksisitas depresi miokard. Pada pasien dengan penyakit kardiovaskular, teknik anestesi regional (baik tunggal atau dengan anestesi umum) bermanfaat perioperatif dalam mengurangi respon stres, simpatektomi jantung, ekstubasi lebih awal, lama rawat di rumah sakit lebih pendek, dan analgesia pascaoperasi yang baik. Selain jenis operasi yang dilakukan, dalam pelaksanaannya juga harus mempertimbangkan masalah yang ada pada masingmasing pasien. Anestesi umum juga memberikan peranan penting karena bersifat kardioprotektif dan dapat meningkatkan suplai oksigen. Keputusan untuk menggunakan anestesi regional harus dilakukan dengan hati-hati dan dilakukan dengan pemantauan yang tepat.

Kata Kunci: anestesi; hemodinamik; jantung; regional; umum

\section{PENDAHULUAN}

Pembiusan pasien dengan penyakit jantung sebelumnya merupakan tantangan yang menarik. Penyebab paling umum morbiditas dan mortalitas perioperatif pada pasien jantung adalah penyakit jantung iskemik (PJI). PJI adalah penyebab nomor satu morbiditas dan mortalitas di seluruh dunia dunia. Sekitar 25 juta pasien di Amerika Serikat yang menjalani operasi setiap tahun, kira-kira 7 juta dianggap berisiko tinggi terkena PJI. Goldman dkk. melaporkan bahwa 500.000 hingga 900.000 (Myocard Infarct) MI terjadi setiap tahun di seluruh dunia dengan mortalitas 10-25\%. Pengelolaan pasien ini memerlukan identifikasi faktorfaktor risiko, evaluasi pra-operasi, optimalisasi, terapi, pemantauan, pilihan teknik anestesi yang tepat, dan obat-obatan. ${ }^{1}$

Keputusan untuk menggunakan anestesi regional tergantung pada banyak faktor: karakteristik pasien, jenis operasi yang direncanakan, dan potensi risiko anestesi; semuanya akan berdampak pada pilihan anestesi dan manajemen perioperatif. Pada pasien dengan penyakit kardiovaskular, teknik anestesi regional (baik tunggal atau dengan anestesi umum) bermanfaat perioperatif dalam mengurangi respon stres, simpatektomi jantung, ekstubasi lebih awal, lama rawat di rumah sakit lebih pendek, dan analgesia pascaoperasi yang baik. ${ }^{2}$ Namun, anestesi regional akan memblok saraf simpatis yang akan menurunkan kontraktilitas miokard, heart rate, terjadinya hipotensi, dan perubahan kondisi jantung. ${ }^{3}$ Meskipun demikian, keputusan untuk menggunakan anestesi regional harus dilakukan dengan hati-hati pada beberapa keadaan. Tujuan bahasan ini adalah untuk memberikan gambaran tentang anestesi regional pada pasien dengan penyakit jantung atau pasien dengan hemodinamik tidak stabil.

\section{FAKTOR RISIKO}

Yang memengaruhi morbiditas jantung perioperatif adalah: (1) infark miokard; (2) gagal jantung kongestif; (3) penyakit pembuluh darah perifer; (4) angina 
pectoris; (5) diabetes melitus; (6) hipertensi; (7) hiperkolesterolemia; (8) usia; (9) disfungsi ginjal; (10) obesitas; (11) gaya hidup dan merokok.

\section{Stratifikasi Risiko}

Pada 1977, Goldman dan rekannya mengusulkan Cardiac Risk Index (Tabel 1). ${ }^{4}$ Meskipun tidak divalidasi secara prospektif, indeks ini digunakan secara luas untuk pra-operasi penilaian risiko jantung selama dua dekade ke depan. Selanjutnya, indeks risiko jantung lainnya diusulkan dan diadopsi. Pada tahun 1996, American College of Cardiology dan American Heart Association (ACC / AHA) menerbitkan pedoman tentang evaluasi kardiovaskular perioperatif pada pasien yang menjalani operasi nonkardiak. Pada tahun 2014, pedoman ini terus diperbarui berdasarkan data baru. $^{5}$

Tabel 1. Cardiac risk index

\begin{tabular}{|c|c|c|c|}
\hline & Variabel risiko jantung & Poin & Keterangan \\
\hline \multicolumn{4}{|c|}{ Goldman cardiac risk index ${ }^{4}$} \\
\hline 1 & Suara jantung ketiga atau distensi vena jugular & 11 & \multirow{9}{*}{$\begin{array}{l}\text { Rate komplikasi jantung: } \\
0-5 \text { poin }=1 \% \\
6-12 \text { poin }=7 \% \\
13-25 \text { poin }=14 \%\end{array}$} \\
\hline 2 & Infark miokard & 10 & \\
\hline 3 & $\begin{array}{l}\text { Irama nonsinus atau Premature Atrial } \\
\text { Contraction }(\mathrm{PAC}) \text { pada EKG }\end{array}$ & 7 & \\
\hline 4 & Lebih dari 5 premature ventricular contractions & 7 & \\
\hline 5 & Usia lebih dari 70 tahun & 5 & \\
\hline 6 & Operasi emergensi & 4 & \\
\hline 7 & Kondisi kesehatan yang buruk & 3 & \\
\hline 8 & Operasi intratorasik, intraperitoneal dan aorta & 3 & \\
\hline 9 & Stenosis aorta & 3 & \\
\hline \multicolumn{4}{|c|}{ Detsky modified multifactorial index ${ }^{6}$} \\
\hline 1 & Angina klas 4 & 20 & \multirow{14}{*}{$\begin{array}{l}\text { Rate komplikasi jantung: } \\
>15 \text { poin= risiko tinggi }\end{array}$} \\
\hline 2 & Suspek stenosis aorta kritis & 20 & \\
\hline 3 & Infark miokard dalam 6 bulan & 10 & \\
\hline 4 & Edema pulmonal alveolar dalam 1 minggu & 10 & \\
\hline 5 & Angina tidak stabil dalam 3 bulan & 10 & \\
\hline 6 & Angina klas 3 & 10 & \\
\hline 7 & Operasi emergensi & 10 & \\
\hline 8 & Infark miokard lebih dari 6 bulan yang lalu & 5 & \\
\hline 9 & $\begin{array}{l}\text { Edema pulmonal alveolar membaik lebih dari } 1 \\
\text { minggu yang lalu }\end{array}$ & 5 & \\
\hline 10 & Irama selain sinus atau PACs pada EKG & 5 & \\
\hline \multirow[t]{2}{*}{11} & Lebih dari 5 Premature Ventricular & 5 & \\
\hline & Contractions (PVC) kapan saja sebelum operasi & & \\
\hline 12 & Status kesehatan umum yang buruk & 5 & \\
\hline & Usia lebih dari 70 tahun & 5 & \\
\hline \multicolumn{4}{|c|}{ Eagle criteria for cardiac risk assessment ${ }^{7}$} \\
\hline 1 & Usia lebih dari 70 tahun & 1 & \multirow{5}{*}{$\begin{array}{l}<1=\text { tanpa tes } \\
1-2=\text { tes non-invasif } \\
>3=\text { angiografi }\end{array}$} \\
\hline 2 & Diabetes & 1 & \\
\hline 3 & Angina & 1 & \\
\hline & Gelombang Q pada EKG & 1 & \\
\hline & Ventricular arrhythmias & 1 & \\
\hline
\end{tabular}




\section{TUJUAN ANESTESI}

Tujuan anestesi pada pasien dengan penyakit jantung adalah pencegahan, deteksi, dan treatment untuk menghindari cedera miokard pascaoperasi. ${ }^{8}$

\section{PERTIMBANGAN PRAANESTESI}

Kunjungan praoperasi ke pasien sangat penting, hubungan baik harus diciptakan dengan pasien dan ditulis persetujuannya. Pasien harus dijelaskan tentang risiko operasi dan anestesi. Hal ini penting untuk melanjutkan obatobatan sampai hari operasi seperti beta blocker, calcium channel blocker, dan digitalis. Kadar kalium harus normal karena hipokalemia dapat menyebabkan toksisitas digitalis. Antikoagulan harus dihentikan.

\section{Premedikasi}

Premedikasi yang baik untuk menghilangkan kecemasan pada pasien jantung sangatlah penting. Untuk mencegah peningkatan tekanan darah dan denyut jantung yang dapat mengganggu suplai oksigen dan demand pada miokard dan dapat menyebabkan iskemia. Obat premedikasi seperti benzodiazepin: lorazepam harus diberikan satu jam sebelum sampai di ruang operasi.

\section{Manajemen Praoperasi}

Tiga terapi pilihan tersedia sebelum operasi elektif non-kardiak: optimalisasi manajemen obat; revaskularisasi dengan PCI; (3) revaskularisasi dengan operasi (CABG)

\section{Pemantauan Intraoperasi}

Insiden iskemia pada periode intraoperasi cukup rendah (dibandingkan dengan periode pra dan pascaoperasi). Adapun pemantauan intraoperasi yang diperlukan: (1) EKG adalah alat pemantauan yang paling umum digunakan. Jika EKG akan digunakan secara efektif sebagai monitor iskemik, monitor harus diatur pada mode diagnostik. Pemantauan tiga lead EKG (II, V4, V5 atau V3, V4, V5) meningkatkan deteksi iskemia. Sistem tren segmen ST juga membantu dalam mendeteksi iskemia; (2) tekanan darah; (3) pulse oksimetri; (4) kapnografi; (5) pemantauan suhu; (6) urin; (7) tekanan vena sentral; (8) tekanan arteri pulmonalis dan cardiac output dapat diukur dengan kateter arteri pulmonalis sesuai kebutuhan. Pada pasien yang secara hemodinamik tidak stabil, syaratnya volume atau inotrop dapat dihitung dan respon dipantau secara ketat; (9) transesophageal echocardiography (TEE) adalah pemantauan yang sensitif untuk iskemia. Namun TEE tidak dianjurkan untuk penggunaan rutin. ${ }^{13}$

\section{ANESTESI PADA PASIEN DENGAN PENYAKIT JANTUNG/ PASIEN DENGAN HEMODINAMIK TIDAK STABIL}

\section{Anestesi Umum}

Tujuan dari induksi anestesi umum adalah untuk menghasilkan ketidaksadaran dan memberikan analgesia, relaksasi otot, dan penekanan respon hemodinamik saat intubasi dan stimulasi bedah.

Ketika intubasi trakea dilakukan, pendekatan yang masuk akal adalah induksi dengan hipnosis kerja pendek (contoh: propofol dosis rendah [sekitar $1 \mathrm{mg} / \mathrm{kg}]$ ) dikombinasikan dengan opioid dosis kecil (contoh, fentanyl 1 hingga $2 \mathrm{mcg} / \mathrm{kg}$ ) dan lidokain 50 hingga $100 \mathrm{mg}$ untuk menumpulkan respon simpatis terhadap laringoskopi dan intubasi. Pelemas otot juga diberikan untuk memfasilitasi laringoskopi. Ketika agen pelumpuh 
otot non-depolarisasi dipilih, kedalaman anestesi dipertahankan atau diperdalam dengan anestesi inhalasi kuat (contoh, sevoflurane atau isoflurane) sambil menunggu beberapa menit untuk kelumpuhan otot yang memadai untuk melakukan intubasi.

Untuk meminimalkan hipotensi, induksi propofol di awal dikurangi dosisnya menjadi sekitar $1 \mathrm{mg} / \mathrm{kg}$ atau kurang, dan suntikan bolus dapat diberikan dalam dosis terbagi pada pasien yang lebih tua dan lainnya yang rentan terhadap terjadinya hipotensi (contoh, pasien dengan penurunan volume intravaskular dan pasien dengan disfungsi diastolik yang bergantung pada preload yang adekuat. Dosis kecil agonis reseptor alfa (contoh, fenilefrin 40 hingga $100 \mathrm{mcg}$ ) dapat diberikan sebagai profilaksis atau jika terjadi hipotensi.

Hindari ketamin pada pasien dengan penyakit jantung iskemik karena biasanya menghasilkan peningkatan yang signifikan dalam denyut jantung, tekanan arteri rerata, dan kadar epinefrin plasma karena stimulasi sistem saraf simpatis yang dimediasi oleh pusat. Peningkatan denyut jantung, sebaiknya dihindari.

Untuk pemeliharaan anestesi, pemberian agen inhalasi volatil atau teknik total intravenous anesthesia (TIVA) adalah pilihan yang masuk akal, berdasarkan faktor-faktor khusus bedah atau spesifik pasien. ${ }^{3,5,10}$ Pada kebanyakan pasien, lebih baik anestesi volatil (contoh, sevoflurane, isoflurane, atau desflurane) sebagai agen utama untuk mempertahankan anestesi umum.

Anestesi volatil mungkin memiliki efek kardioprotektif secara in vitro, ${ }^{16}$ Namun hal ini belum terbukti signifikan secara klinis pada pasien yang menjalani operasi nonkardiak. Dalam sebuah tinjauan sistematis tahun 2016 dari 45 percobaan acak dari efek anestesi volatil versus TIVA pada mortalitas dan morbiditas pascaoperasi pada pasien yang menjalani anestesi umum. Agen anestesi volatil secara signifikan mengurangi keseluruhan kejadian jantung dan morbiditas pascaoperasi pada pasien yang menjalani operasi jantung, tetapi tidak pada pasien yang menjalani operasi nonkardiak. ${ }^{17}$

\section{Anestesi Regional}

Potensi dan keunggulan anestesi regional sudah diketahui melebihi anestesi umum, menjadi keuntungan pada pasien jantung jika operasi dapat dilakukan dengan blok regional. Pasien harus diberi premedikasi agar tidak cemas. Kerugian dari anestesi regional termasuk hipotensi dari blokade simpatis yang tidak terkendali dan kebutuhan untuk loading volume dapat menyebabkan iskemia. Tatalaksana harus diambil saat memberikan anestesi lokal karena dosis yang lebih besar dapat menyebabkan toksisitas dan depresi miokard. Menggunakan epinefrin sebagai adjuvan dengan anestesi lokal tidak disarankan. ${ }^{18}$ Takikardi adalah satu-satunya kejadian paling umum yang sering dikaitkan dengan iskemia dan menyebabkan peningkatan demand dan penurunan suplai oksigen yang dapat membahayakan miokardium dan rentan menyebabkan perubahan iskemik pada pasien. ${ }^{19}$

Anestesi neuraksial dapat menurunkan preload jantung akibat blokade simpatis. Ini lebih mungkin terjadi pada pasien dengan penurunan volume intravaskular atau gagal jantung dan disfungsi diastolik yang bergantung pada preload yang adekuat. Pada pasien 
dengan hemodinamik tidak stabil, dapat menggunakan teknik anestesi neuraksial yang dimodifikasi (contoh, kombinasi dosis rendah spinal-epidural dengan atau tanpa opioid intratekal, atau anestesi epidural yang dititrasi secara perlahan).

Selama onset blok, cairan diberikan untuk mencegah hipotensi. Namun, hindari overhidrasi atau pemberian bolus cepat cairan dalam jumlah banyak pada pasien dengan gejala gagal jantung. Restriksi cairan kristaloid dan pemberian yang lebih lambat lebih baik (contoh, pemberian penambahan 250 $\mathrm{mL}$ sesuai kebutuhan, dengan pemantauan hemodinamik pasien dan respon klinis untuk setiap penambahan). ${ }^{14}$

Vasopressor sering diperlukan untuk mengembalikan tekanan darah ke kadar mendekati baseline. Hipotensi yang signifikan dikoreksi cepat dengan memberikan agonis reseptor alfa (contoh, fenilefrin 40 hingga $100 \mathrm{mcg}$ ) atau simpatomimetik langsung/ tidak langsung dengan efek agonis beta dan alfa (contoh efedrin 5 hingga $10 \mathrm{mg}$ ), dengan dosis berulang sesuai kebutuhan. ${ }^{14}$

\section{PERBANDINGAN TEKNIK ANESTESI REGIONAL DENGAN ANESTESI UMUM}

Berikut alasan perbandingan teknik anestesi regional dan anestesi umum: (1) anestesi umum (GA) efektif, mudah diaplikasikan dan menawarkan kondisi operasi yang optimal, khususnya selama prosedur jangka panjang. Namun demikian, disfungsi kognitif pascaoperasi dan delirium pascaoperasi sering dikaitkan dengan GA, serta efek samping kardiopulmonal; perkembangan teknik pembedahan yang sedikit invasif seperti endovascular treatment untuk aortic aneurysms, laparaskopi atau prosedur robotassisted; (3) anestesi regional membutuhkan keterampilan yang lebih spesifik dari ahli anestesi dan komunikasi dengan pasien. Selain itu anestesi regional memiliki tingkat kegagalan tertentu (tergantung teknik dan operator) dan memiliki komplikasinya sendiri: toksisitas anestesi lokal, perdarahan, komplikasi terkait saraf seperti transient neurologic symptoms (TNS), cedera saraf tepi, hematoma epidural, abses epidural, dan meningitis serta anterior spinal artery syndrome; (4) anestesi regional pada dasarnya beragam teknik, yang satu lebih invasif dibanding yang lain dan hanya sesuai untuk indikasi yang spesifik; (5) penggunaan obat antikoagulan merupakan kontradikasi utama anestesi regional.

\section{Manajemen Komplikasi Intraoperasi ${ }^{1}$}

1. Iskemik intraoperasi

1.1 Jika pasien dengan hemodinamik stabil: (1) beta blockers (I/V metoprolol sampai $15 \mathrm{mg}$ ); (2) I/V nitrogliserin (3) heparin setelah konsultasi dengan ahli bedah

1.2 Jika pasien dengan hemodinamik tidak stabil: (1) support dengan inotrop; (2) gunakan ballon pump intraoperative mungkin dibutuhkan; (3) konsultasi segera dengan ahli jantung untuk merencanakan sedini mungkin kateterisasi jantung

2 Komplikasi lain seperti disritmia, disfungsi pacemaker harus dikelola dengan baik. 
MANAJEMEN PASCAOPERASI

\section{Pemantauan cedera miokard}

Mayoritas myocardial injury in noncardiac surgery (MINS) terjadi selama periode pascaoperasi. ${ }^{10}$ Untuk pasien dengan penyakit jantung iskemik dengan risiko tinggi (Tabel 2), tindakan pencegahan termasuk pemantauan terus menerus elektrokardiografi (EKG) di unit perawatan pasca-anestesi dan kemudian di unit perawatan intensif sehingga takikardi dapat dihindari atau diobati, ${ }^{21}$ dan adanya iskemia dapat dideteksi.

Tabel 2. Revised cardiac risk index (RCRI)

Enam prediktor independen dari komplikasi jantung mayor ${ }^{22}$

Tipe operasi berisiko tinggi (contoh operasi vaskular dan intraperitoneal terbuka atau prosedur intrathorak)

Riwayat penyakit jantung iskemik

Riwayat gagal jantung

Riwayat penyakit serebrovaskular

Diabetes melitus yang memerlukan terapi insulin

Serum kreatinin preoperatif $>2.0 \mathrm{mg} / \mathrm{dL}$ (177 micromol/L)

Persentase cardiac death, nonfatal myocardial infarction, nonfatal cardiac arrest berdasarkan jumlah prediktor ${ }^{23}$

Tanpa faktor risiko - $0.4 \%$ (95\% CI: $0.1-0.8)$

Satu faktor risiko - $1.0 \%(95 \%$ CI: $0.5-1.4)$

Dua faktor risiko $-2.4 \%(95 \%$ CI: $1.3-3.5)$

Tiga atau lebih faktor risiko - 5.4\% (95\% CI: 2.8-7.9)

Persentase myocardial infarction, pulmonary edema, ventricular fibrillation, primary cardiac arrest, dan complete heart block ${ }^{22}$

Tanpa faktor risiko - 0.5\% (95\% CI: 0.2-1.1)

Satu faktor risiko - $1.3 \%$ (95\% CI: 0.7-2.1)

Dua faktor risiko - 3.6\% (95\% CI: 2.1-5.6)

Tiga atau lebih faktor risiko - 9.1\% (95\% CI: 5.5-13.8)

\section{Manajemen nyeri}

Manajemen nyeri pascaoperasi yang penting efektif untuk menghindari stres, gejolak hemodinamik, dan hiperkoagulasi. ${ }^{10}$ Untuk pasien kooperatif tanpa kontraindikasi yang menjalani operasi abdominal atau thoraks mayor dengan insisi besar, anestesi epidural disarankan untuk analgesia preemptive pascaoperasi. Sebagai alternatif, pemberian opioid subarachnoid yang bekerja lebih lama (contoh, morfin atau hidromorfon) dapat memberikan 12 hingga 24 jam analgesia pascaoperasi.

Volume 11, Nomor 1, Tahun 2019
Teknik anestesi regional spesifik juga efektif, dan ini dipilih berdasarkan lokasi pembedahan dan prosedur (contoh: blok pleksus brakhialis untuk nyeri ekstremitas atas; femoral atau blok saraf sciatic untuk nyeri ekstremitas bawah; blok saraf interkostal atau paravertebralis untuk prosedur payudara, dada, atau perut bagian atas).

Teknik lain untuk manajemen nyeri pascaoperasi adalah patient-controlled analgesia (PCA). ${ }^{24}$ Obat antiinflamasi nonsteroid (NSAID) dan siklooksigenase-2 (COX-2) inhibitor dihindari pada pasien dengan iskemia miokard; obat ini berisiko pada 
kardiovaskular, ${ }^{3}$ seperti: cardiovascular death, infark miokard (MI), dan stroke.

Kejadian penting lainnya termasuk gagal jantung, peningkatan tekanan darah, fibrilasi atrium, dan tromboemboli vena. ${ }^{25}$

\section{RINGKASAN}

Pada pasien dengan penyakit kardiovaskular, teknik anestesi regional (baik tunggal atau dengan anestesi umum) berpotensi bermanfaat perioperasi dalam mengurangi respon stres, simpatektomi jantung, ekstubasi lebih awal, lama rawat di rumah sakit lebih pendek, dan analgesia pascaoperasi yang baik. Anestesi umum memiliki sifat kardioprotektif dan dapat meningkatkan suplai oksigen. Keputusan untuk menggunakan anestesi regional harus dilakukan dengan hati-hati dan dilakukan dengan pemantauan yang tepat. Perhatian harus diberikan pada penggunaan antikoagulasi, menimbang potensi risiko tromboemboli ketika menghentikan antikoagulasi dengan manfaatnya.

\section{DAFTAR PUSTAKA}

1. Kaul TK, Tayal G. Anaesthetic Considerations in Cardiac Patients Undergoing Non Cardiac Surgery. 2007;51(6):280-6.

2. Kraus M, Asgarian CD, Koyyalamudi V, Tran L, Alvord $\mathrm{J}$, Kaye AD, et al. Regional Anesthesia and Cardiovascular Disease. Essentials Reg Anesth. 2018;529-40.

3. Kristensen SD, Knuuti J, Saraste A, Anker S, Bøtker HE, De Hert $\mathrm{S}$, et al. 2014 ESC/ESA Guidelines on non-cardiac surgery: Cardiovascular assessment and management: The Joint Task Force on noncardiac surgery: Cardiovascular assessment and management of the European Society of Cardiology (ESC) and the European Society of Anaesth. Eur Heart J. 2014;35(35):2383431.

4. Goldman L, Caldera D, Nussbaum S, et al. Multifactorial index of cardiac risk in noncardiac surgical procedures. N Engl J Med 1977;297:845.

5. Fleisher LA, Fleischmann KE, Auerbach AD, Barnason SA, Beckman JA, Bozkurt B, et al. 2014 ACC/AHA Guideline on Perioperative Cardiovascular Evaluation and Management of Patients Undergoing Noncardiac Surgery: Executive Summary [Internet]. Vol. 130, Circulation. 2014. 2215-2245 p. Available from:

https://www.ahajournals.org/doi/ 10.1161/CIR.0000000000000105

6. DetskyAS, Abrams HB, Forbath $\mathrm{N}$, et al. Cardiac assessment for patients undergoing noncardiac surgery.Amultifactorial clinical risk index. Arch InternMed 1986; 146:2131.

7. Eagle K, Brundage B, Chaitman $\mathrm{B}$, et al. Guidelines for perioperative cardiovascular evaluation for non-cardiac surgery. AHA/ACC task force report. J Am Coll Cardiol 1996; 27:910.

8. Abbott TEF, Pearse RM, Archbold RA, et al. A Prospective International Multicentre Cohort Study of Intraoperative Heart Rate and Systolic Blood Pressure and Myocardial Injury After Noncardiac Surgery: Results of the VISION Study. Anesth Analg 2018; 126:19.

9. Helwani MA, Amin A, Lavigne 
P, et al. Etiology of Acute Coronary Syndrome after Noncardiac Surgery. Anesthesiology 2018; 128:1084.

10. Fleisher LA, Fleischmann KE, Auerbach AD, et al. 2014 ACC/AHA guideline on perioperative cardiovascular evaluation and management of patients undergoing noncardiac surgery: executive summary: a report of the American College of Cardiology/American Heart A.

11. Eagle KA, Berger PB, Calkins H, et al. ACC/AHA guideline update for perioperative cardiovascular evaluation for noncardiac surgery-executive summary.Areport of theAmerican College of Cardiology /American HeartAssociation Task Force on Practice Guidelines .

12. Dupuis JY, Labinaz M. Noncardiac surgery in patients with coronary artery stent: what should the anaesthesiologist know? Can JAnaesth 2005;52:356.

13. Barash PG. Sequential monitoring of myocardial ischemia in the perioperative period. In:American Society of Anaesthesiologists Review Lectures. Atlanta: American Society of Anaesthesiology;2005.p.411.

14. Nadia, Blakemore Hensley; Charles WH. Anesthesia for noncardiac surgery in patients with ischemic heart disease. uptodate. 2019; Jan.

15. Bruder EA, Ball IM, Ridi S, et al. Single induction dose of etomidate versus other induction agents for endotracheal intubation in critically ill patients. Cochrane Database Syst
Rev 2015; 1:CD010225.

16. Agarwal B, Stowe DF, Dash RK, et al. Mitochondrial targets for volatile anesthetics against cardiac ischemia-reperfusion injury. Front Physiol 2014; 5:341.

17. Uhlig C, Bluth T, Schwarz K, et al. Effects of Volatile Anesthetics on Mortality and Postoperative Pulmonary and Other Complications in Patients Undergoing Surgery: A Systematic Review and Metaanalysis. Anesthesiology 2016; 124:1230.

18. Breen P, ParkKW. General anesthesia versus regional anesthesia. IntAnesthesiol Clin 2002; 40:61.

19. Madhusudhana R, Rajendra N. Anesthetic management of a patient with ischemic heart disease posted for open reduction internal fixation of the upper limb. Karnataka Anaesth J. 2015;1(2):69.

20. Breivik H. Occurens of chronic pain after surgery. In: Refresher Course Lectures. Vienna: Euroanesthesia Austria; 2005. p. 231-2.

21. Sigmund AE, Fang Y, Chin M, et al. Postoperative Tachycardia: Clinically Meaningful or Benign Consequence of Orthopedic Surgery? Mayo Clin Proc 2017; 92:98.

22. Lee TH, Marcantonio ER, Mangione CM, et al. Derivation and prospective validation of a simple index for prediction of cardiac risk of major noncardiac surgery. Circulation 1999; 100:1043.

23. Devereaux PJ, Goldman L, Cook DJ, et al. Perioperative cardiac events in patients undergoing 
noncardiac surgery: A review of the magnitude of the problem, the pathophysiology of the events, and methods to estimate and communicate risk. CMAJ 2005; 173:627.
24. Edward R M. Management of acute perioperative pain. Elsiever. 2015;UpToDate(figure 2):1-52.

25. Allen C. Adverse cardiovascular effects of NSAIDs. Inpharma Wkly. 2005;NA;(1508):19-20. 